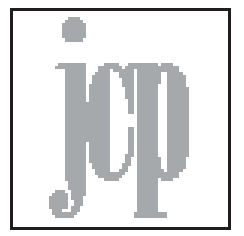

\title{
The Musealisation of Istanbul in Orhan Pamuk's Museum of Innocence
}

\author{
Uzma Abid Ansaari \\ Department of English | International Islamic University Islamabad \\ uzma.abid@gmail.com
}

\begin{abstract}
This essay examines Turkish author Orhan Pamuk's work of fiction The Museum of Innocence and his memoirs Istanbul: Memories and the City. It explores the motif of the fetishistic collection of mundane paraphernalia from urban living and the subsequent musealisation of the material culture of the city of Istanbul. It first looks at the concept of musealisation, and its historical connections with the process of modernisaton and the formation of the nation state since it helped institutionalise the narrative of the state. It traces the development of the museum from a pedagogic urban space to a state institution which perpetuates the myth behind the nation state. It then examines the role of Pamuk himself as expository agent in his private museum, the Museum of Innocence, based on his work of fiction by the same name. Pamuk's subjectivity as expository agent is identified as being self-reflexive. This essay explores the possibilities this self-reflexivity creates for Pamuk's work with respect to his manifesto for creating "small museums" as opposed to grand state museums, and thus creating a counter-narrative to that of the state narrative. Lastly, it analyses the motif of 'hüzün' deployed time and again by Pamuk in order to paint a picture of Istanbul which embodies the melancholy of the city. This essay demonstrates the ways in which hüzün functions as an emotional space which blurs the boundaries between public and private spaces in the city, and also effectively delinks the private museum from the grand public museums sponsored by the state by creating an ambivalent space which is both public and private within the private museum.
\end{abstract}

Keywords: Modernisation, progressivism, nation state, museology, urban spaces 
Turkish author and Nobel laureate, Orhan Pamuk, in his critical essays Other Colours, defines himself as a writer who appeals to the visual imagination rather than the verbal imagination. When reading his works, one finds that the landscape which directly influences his writing is the urban landscape of Turkey, most significantly his hometown Istanbul. Being a visual novelist, Pamuk has fully explored, and is still exploring, the city in all its vitality, growth and contradictions. More than being a Turkish citizen, Pamuk considers himself to be an Istanbullu, a native of the city and a product of its history and culture. In this sense, his self-identification as being a native of a city rather than a country i.e. Turkey, creates a distance between him and the nation state, because it recognises the multiplicity of identities which intersect to create a unique identity of a city dweller. In light of this critical outlook of Pamuk's, this essay examines his engagement with the modern city of Istanbul, and it specifically foregrounds the significance of the museum as part of the 'modernising project' in the formation of the Turkish nation state.

Museums are seen as institutions directly related to a European colonial legacy that helped to crystallise western hegemonic epistemes and the power structures they validated and perpetuated. They functioned by creating a 'national' history of not only Turkey but also most nation states for that matter. This essay demonstrates how Pamuk develops the concept of a museum with a counternarrative, a museum of 'innocence' which disengages from the grand narrative of a state-sponsored museum; and how at the same time it is embedded in the hüzün drenched cityscape of Istanbul as both a public and a private space.

Pamuk's fascination with the city surfaces in almost all of his works but most acutely in his novel The Museum of Innocence. Centred on a man, Kemal, infatuated with a young distant cousin called Füsun, and his fetishising of her, the plot is merged into the 'texture' of the city, the colour and feel of Istanbul, as the city's materiality comes to reflect the protagonist's obsession with a former lover. The objects within, and of, the city come to define a single man's life, specifically a man from the Çukurcuma district where the house of the protagonist's love interest is located and which he eventually makes his home after her family moves out. The narrative, although not autobiographical, does, in more ways than one, reflect Pamuk's own relationship with the city, which is most evident in the material existence of an actual Museum of Innocence built by Pamuk (based on the novel) located in the old Çukurcuma district. This museum also contributes to the topography of the cityscape in its own quaint way. Çukurcuma was previously a derelict area of central Istanbul, part of the old city, but it has recently emerged as a hot spot of local cultural experience, and it is close to where Pamuk himself 
has taken up residence, moving to this district from the upscale location of his family house.

\section{Musealising the City}

Taking a cue from the theme of material culture and an obsession with objects of the city in this work, I will be looking at the phenomenon of modernity depicted therein by deploying the concept of 'musealisation' to analyse the motif of museums and collecting in The Museum of Innocence. Andreas Huyssen has used the term 'musealisation' in relation to the contemporary process of "collecting, citing, and appropriating" of mundane objects and images. This museal sensibility accompanied the wave of western modernisation which homogenised global culture to a considerable extent, varying from region to region depending on its geo-political location on the globe. Turkey's case is unique since it was almost colonised but was made a Republic just before it was to be divided up into pieces and shared among the Allies during the First World War. But before it became a Republic, however, the Tanzimat in the Ottoman Empire were already working towards creating an empire that would be more welcoming of modernisation and the enlightenment project of 'civilisation' by incorporating organisational and institutional changes based on the western model (Kerpat). Although, earlier on, during the 'pre-modern' or even 'pre-Turkic' period, collection practices were restricted to the re-use of Hellenistic and Christian architectural remains or as found in private collections, right after the Tanzimat, in 1869, the word collection was replaced by 'museum' and such collections were put on public display for the first time; and the first autonomous museum was institutionalised in 1889, a few decades before the formation of the Turkish republic in 1923 (Shaw 32). Huyssen notes that the museal sensibility which rose out of a sense of loss of the past and the need to preserve that past at least in its materiality in the face of sterile modernisation is also a western phenomenon.

The popularity of the museum is, I think, a major cultural symptom of the crisis of the western faith in modernisation as panacea. One way of judging its activities must be to determine to what extent it helps overcome the insidious ideology of the superiority of one culture over all others in space and time, to what extent and in what ways it opens itself to other representations and how it will be able to foreground problems of representations, narrative, and memory in its designs and exhibits. (Huyssen 34)

The ideological belief in the superiority of one culture over another in the preservation of artefacts belonging to 'other' cultures for pedagogical purposes that perpetuate such power relations has not escaped Pamuk's eye. He is vocal in differentiating between his own Museum of Innocence and a normative museum. 
In an interview with Nathan Gardels, he states:

The habit of collecting, of attachment to things, is an essential human trait. But Western civilisation put collecting on a pedestal by inventing museums. Museums are about representing power. It could be the king's power or, later, people's power. (Pamuk)

Pamuk makes an association between power and putting collections on display. This is an interesting power relation which demonstrates the potency of a pedagogical space that allows the gaze of the viewer to scrutinise an object put on display in this space. He recognises the fact that preservation, putting on display and musealising, endows the agent of the process of musealiation, i.e., the curator or sponsor of the museum with immense power that can hegemonise peripheral perspectives and epistemes. This agency had historically belonged to the monarchy and, later, to the people, which could potentially mean the common man as well as the modern nation state. It is, however, understood that, by and large, this agency, to create pedagogical spaces where certain objects are put on display for amusement as well as for reinforcing cultural norms or dominant discourses, belongs to the state. Pamuk makes an historical connection between the museum as a state-sponsored institution and modern western civilisation and not with the non-western world which was characterised by the odd individual collector. Later, however, with the creation of nation states in the 'non-west', public museums became vital for the state:

However, in the last 50 years, the non-Western world is catching up with museums because it wants to represent its power. Most of the time such museums are about the power of the state. They are crude exercises, like waving a flag. This new museum mania avoids representing reality in an artistic or personal way. Power is more important than art or the person. That is the trend. (Pamuk)

The Museum of Innocence, on the other hand, is a break away from this power dynamic between objects and curators/museum sponsors, and it houses mundane objects taken from the urban material culture of Istanbul from the mid to late twentieth century. Each exhibit in the museum is aligned to a chapter from the novel The Museum of Innocence, and it is accordingly captioned with the title and number of the chapter it represents. For example, the exhibit 30, captioned "Füsun Doesn't Live Here Anymore", showcases a (full) teacup and saucer, a decorative piece shaped like a lying dog, and a small cut-crystal bowl. These three objects are commonplace items easily found in many middle-class drawing rooms, and they were also present in Füsun's parents' house where Kemal went looking for her and was told politely that Füsun had moved out. Then an exhibit for Chapter 40 is called "The Consolations of Living in a Yali". 
It features monochrome photographs of Istanbul and items of food and drink. It represents Kemal's retreat to his family 'yali', a wooden villa on the shores of the Bosphorus of a type traditionally owned by wealthy families from Istanbul. Many of these yalis were destroyed by fires at various times during the course of the 20th century, and Istanbul lost an important component of its cityscape. Another exhibit, number 49, captioned "I was Going to Ask Her to Marry Me" displays the objects found in Füsun's parents' bathroom as Kemal goes there to gather himself together before he asks for her hand in marriage. He is unable to do so because soon afterwards he finds out that Füsun has married someone else. All these objects displayed in the museum have no significance other than in relation to the narrative fiction of a novel, and they carry affective value which would have diminished with time had they not been preserved in such a calibrated fashion and 'synecdochically' connected to a larger framework, i.e. they do not carry any meaning freestanding in the space and context of the Museum of Innocence. I will elaborate on the 'synecdochical' quality of Pamuk's museum later.

The key issues that emerge within the framework of Pamuk's 'musealisation' of urban modernity in the form of preserved material cultural objects are concerned with the relationship between urban individuals and objects of mundane utility, which would make the Museum of Innocence an unlikely state institution, considering that museums are generally public, state-owned spaces that promulgate state ideology. Although the relationship between people and objects develops in a historical and social context based on the experiences shaped by these external socio-historical factors, the objects housed in Pamuk's Museum are imbued with a significance that surpasses their exchange value and is not in any way instrumental in a pedagogic purpose. Pamuk's attempt to musealise such objects not only freezes in time the experiential value attached to them but also contests the urban museum as a pedagogical space asserting and projecting the power relations between a modern state and the 'other', which in relation to the state could be anything that falls outside the modern nationalist discourse of the state and could even potentially oppose its ideology.

Pamuk, as a writer and even as a collector, thus meticulously documents and catalogues the constituents of urban life in the late modern period and early republican period of Istanbul. He exposes the intimate relationship between objects that are representative of urban life and national identity, which acted as a prompt to acquire these objects in the first place. This was because the birth of the nation state was accompanied by a simultaneous industrialism which not only pushed for progress through rapid industrialisation but also saw an increase in a 
consumer culture as a new, nationally-conscious middle class inclined towards a fast-paced urban lifestyle that emerged in the cities (Brown).

The 'Museum of Innocence' functions as a space which, in emulating a normative modern museum, puts the very paraphernalia of modern material culture and consumer products on display as curiosities from an obsolete time. In doing so it has become a dialectical space that turns the notion of modernity on itself by subjecting the modern lifestyle to a modern gaze. This creates an interesting paradox because an individual who considers him/herself to be 'modern' would epistemically be inclined to demythologise any traditional narrative and advocate the 'new', making a break away from the old or traditional. In this scenario, however, 'the new' is pitted against 'the new' itself. The modern visitor to the museum is made to turn his/her objectifying gaze on his/her own mundane reality and strip it of idealised notions of progress. Objects of daily use housed in the Museum of Innocence are from the second half of the 20th century and mostly consist of industrial products that once carried utilitarian value which depreciated with the passage of time. What remains preserved in the Museum are objects that have no utility as such, but which, nevertheless, tell tales of lives embroiled in rapid urbanisation, industrialisation and the rhetoric of progress. Thus, the modern visitors to the Museum are confronted by a historicisation of the notion of progress and they are made to feel like outsiders in relation to the process of modernisation. In other words, Pamuk's museum functions on the basis of the gaze of the museum visitor who has been 'conditioned' to be scientific and deductive. In the case of the Museum of Innocence, it ironically looks at modern material culture with the classificatory and ultimately reductionist outlook of modernity itself.

\section{Pamuk as “an Expository Agent”}

Given the history of the museum as an institution that concurred with and abetted the vast and ambitious project of the Enlightenment, Pamuk's Museum of Innocence stands out as an antithesis to the modern age, in other words, a postmodern structure offering a counter-narrative to the universalising narrative of the state institution. There are two reasons for this. First, there is the scale of the museum which is very small and personal, yet organised and administered like any other exhibitory space. Second, there is the fact that it is based on a completely fictitious narrative. In order to appreciate the cultural significance of this museum, the relationships between the role that Pamuk plays in its narrative as expository agent, the objects on display, and the visitor to the museum need to be analysed and understood. In Double Exposures, Mieke Bal defines an 
“expository agent” as a subject of exposing (157). The relationships among an expository agent, the objects on display and the visitors are, of course, not unique to Pamuk's museum, and they are the generic structure in the communication of any narrative in museology. According to Bal, this structure has developed a paradigm of museology that can be used in the field of cultural analysis.

The expository agency that she refers to is a cultural practice, "and the cultural politics and divisions that enable that practice, not an individual and his or her personal intentions" (Bal 2) and, by positing Pamuk as the expository agent, I argue that his subjectivity is in actuality self-reflexive. This means that, while Pamuk plays the role of an apparently neutral or Cartesian narrator, his predisposition and intent are already known to the visitor. In her thesis, Bal proposes a "homeopathic" (62) cure to the scientific and Cartesian organisations of both ethnographic museums and art museums, a cure which endorses confusion, the suspension of categories and contamination among the elements of exposition which can be realised if the expository agent is self-reflexive and hence not objective. The Museum of Innocence functions as a normative museum because it relies on, and takes for granted, the tendency of the modern visitor to "believe in the truth of the knowledge represented through fiction" (53), yet, at the same time, it points to its own 'fiction' (being based on a fictive narrative) because it relies on the visitor to have read the narrative fiction to which the museum is a monument. The expository agent is an important aspect of the museum because $\mathrm{s} /$ he is the subject who structures the museum as a meaning-making space for the lay visitor and, if the expository agent includes the contrivances of this space in the exposition, s/he becomes self-reflexive. The museum as a state institution is anything but self-reflexive, and Bal's paradigmatic utilisation of museology for cultural analysis helps to break down the first person narrative of the expository agent, thus exposing its dependency on the second person (the visitor) and hence questioning its agency and neutrality. She states something very interesting in this respect:

Museums emerged with the colonisation of the world; we are now facing the end of that phase in the history that the project of conservation tried to freeze[...]. We may be approaching the end of the museum or we may not; but we are certainly approaching the end of its disingenuous innocence. (70) According to Bal, state-sponsored museums are not as innocent as they seem because they generate a narrative that relies on certain discursive strategies, which were largely determined by the colonisation of the world in the modern era. This practice which she calls "discursive museology" (76) because it is based on certain discursive perspectives which, broadly speaking, categorise institutions into 
ethnographic museums and art museums. Within these two frameworks certain discursive strategies are set in motion and obscure the issues of colonialism (in relation to the institution of the museum), such as diminishing native culture through rhetoric. Since discursivity is "most notably rhetoric imbricated with narrative [it] is a crucial aspect of the institution", and it follows that the institution is framed by two rhetorical devices, the metaphor and the synecdoche, which determine whether it will be an art museum or an ethnographic museum (77). Where a metaphorical discourse is framed by the narrative of an art museum, thus rendering universal the aesthetic of the art works on display irrespective of their culture of origin, the narrative of the ethnographic museum frames a synecdochical discourse because the objects housed therein are considered to be parts or fragments of a larger culture, one which they represent in their capacity as cultural artefacts.

Here, I would like to focus on, and draw attention to, the rhetorical instrumentalisation of synecdoche in discursive museology because it delimits the 'artefact' to its culture of origin. It, thus, cuts it off from any metaphorical readings that could have an aesthetic appeal which trespasses over cultural boundaries and which, according to Bal, embody a synecdochical logic. Fetishism, which is an obsessive collection of objects related to or having some kind of connection with a larger whole-a person or a culture-carries a synecdochical logic and is especially pertinent to collectors and their collections. This has particular relevance to Pamuk's Museum of Innocence which makes for an allthe-more thought-provoking case study since the objects put on display do not belong in the category of ethnography, yet the narrative of the museum deploys a synecdochical discourse.

The objects on exhibit in Pamuk's museum are elements of the narrative put forth in the novel The Museum of Innocence. If each exhibit in its glass case was isolated from the narrative, there would be no question of a metaphorical reading that could yield a universal aesthetic meaning from them, because, if the visitor has not read the novel and is not familiar with its narrative, for that visitor Pamuk's museum will have no meaning. An ethnographic museum is similar in this way to this case study because, without the act of 'pointing to' and captioning exhibits which produces a narrative by a sequential linking of the elements of the exhibition, the artefacts will hold no meaning. This essentially betrays the anxiety of the ethnographic museum in that it does not allow the objects to speak on their own and delimits their meaning to a place of origin. The narrative of the museum makes the contextualisation of the artefacts essential to a 'reading' of 
the museum discourse, because otherwise it denies them aesthetic transcendence which is achieved through a metaphorical reading and also because its discourse demands a knowledge of the culture of origin prior to viewing the objects. This implies that meaning-making strategies through snippets of information on the captions placed on the artefacts are suggested to the visitor by the expository agent, because the viewer's status as the addressee of the narrative is crucial in meaning making, vision being "an act of interpretation, a construction out of nothingness" that bestows value on the objects on display (79). How the Museum of Innocence's synecdochical logic contradicts the narrative of the state institution will be discussed further in the following sections.

The deployment of rhetorical devices in the narrative endorsed by the institution and the very structure of a museum imply a discourse which requires being read. According to Bal, this is a necessary perspective on the museum as a state institution, because "such a perspective deprives the museum practice of its innocence, and provides it with accountability it, as well as its users, are entitled to" (128). What strips the museum practice of its innocence is the deceptive objectivity of the Cartesian subject, the expository agent who remains invisible throughout nevertheless suggests meaning-making strategies to the secondperson, the visitor, who is guided through the museum via a historiographic and progressivist narrative. The invisible and apparently neutral expository agent uses the medium of the exhibitionary space of the museum to unfold a thirdperson narrative that is suggestive of omniscience not unlike the omniscient and omnipresent narrator of a fiction novel, and in this way the first person subjectivity passes off as a third-person perspective. This all-knowing narrator is akin to the traditional Cartesian subject because they make claims for objective truth and impersonal knowledge that are reflected in the logically categorised exhibits whose design gives paradigmatic status to physics as the ideal model of knowledge, because this science relies on "observational samples" (171). Bal argues in favour of a critique of this narrative that is reliant on a deceptive objectivity because the perspective that demands a 'reading' of the discursive strategies of such a narrative cannot ignore the addressee, the second person or the visitor to the museum, because, without them, the expository agent cannot be defined and loses his/her personhood.

In contrast, Pamuk creates and instrumentalises the paradigm of museology to expose himself as an expository agent by deliberately crafting a narrative in the form of his novel The Museum of Innocence for a corporeal museum of the same name, and, in doing so, he also draws attention to the production 
of knowledge by privileged subjectivities or first person perspectives, vis-à-vis 'modern' or 'western style' museums. In this respect, his text is like an expository discourse found in any other museum but one that is self-analytical and selfreflexive, so that it poses a challenge to both nineteenth-century realism and absolutist narratives. Reality becomes surreal in the novel when the agency of the omniscient author collapses as the narrator Kemal includes and addresses Pamuk in the fictional narrative, and also when the author's identity conflates with the character Kemal:

It was just after my return from one such journey that, after telling him my story, and describing the museums I'd visited, I asked him how the novel was progressing.

"I am writing the novel in the first person singular," said Orhan Bey.

"What do you mean?"

"In the book you are telling your own story, and saying 'I,' Kemal Bey. I am speaking in your voice. Right now I am trying very hard to put myself in your place, to be you."

"I understand," I said. "So tell me, have you ever been in love this way, Orhan Bey?"

"Hmmmmm[...] We aren't talking about me," he said, and he fell silent. (Pamuk 515)

Like Kemal, Pamuk also visited museums in Europe, but what intrigued him was not the imposing state institutions promulgating modern art or ethnography. In a blog he wrote for T Magazine (New York Times Style Magazine), entitled "Small Museums", he listed five museums that inspired the layout of his Museum of Innocence in Istanbul (Pamuk). These were the Gustave Moreua Museum in Paris, the Bagatti Volsecchi Museum in Milan, the Frederic Mares Museum in Barcelona, the Rockox House Museum in Antwerp, and the Mario Praz Museum in Rome. Although located in different cities in Europe, the common denominator of these museums is the mode of their conception because, prior to being museums, all were private residences of collectors, artists and art historians. Not only were they private residences but they also house, as objects on display, solely private collections of furniture, decorative and art objects, and other paraphernalia of a mundane nature. Pamuk says that he finds more pleasure in these small museums because of the "connection between objects and personal dramas and to feel that metaphysical sense of time" (n.p.) that he believes museums must be able to convey. True enough, these private museums tend to encapsulate and suspend time in a single space in contrast to the normative sense of a linear chronology that is projected by museums on the state level. In the same essay, Pamuk speaks of a distinctive ambience particular to each of these 
small museums. This ambience is not only a product of the personal nature of the collection housed in such a museum but is "envisioned by those who set it" (n.p.), implying a deliberation over the affect produced by the display. Such museums bring out our individuality, and this is what Pamuk aspired to 'set up' when he conceived the Museum of Innocence.

Given the critique accorded to museums on the national level, Pamuk has positioned himself somewhere at a distance from the nationalistic and progressivist epistemology espoused by the institution of the museum, yet, at the same time, he has embraced the "small" museum which he states is a testimony to individuality and personhood. Although he comes across as a little apologetic for distancing himself from mega institutions such as the Louvre and the British Museum, he openly criticises, without mincing his words and on the same lines discussed above, state museums in non-western countries, like Beijing and Abu Dhabi, as symbols of state and national power, "acting as smoke screens for the crimes of authoritarian regimes" (Pamuk). He does not touch upon the colonial legacy and its crimes upon which the Louvre and the British Museum were founded but, nevertheless, puts his point across that small museums are far more enthralling as far as he is concerned.

\section{Hüzün:The Space between the Public and the Private}

In the fragmented narrative of Istanbul: Memories and the City, the chapters that dwell on hüzün are narrative expositions of the city that place Pamuk in the position of an expository agent who lays out the constituents of his city as objects on exhibition and also tints them with the colour of his own hüzün. Pamuk describes hüzün in chapter ten of his memoirs:

According to the first tradition, we experience the thing called hüzün when we have invested too much in worldly pleasures and material gain[...] The second tradition, which rises out of Sufi mysticism, offers a more positive and compassionate understanding of the word and of the place of loss and grief in life.

[...]But for El Kindi, who saw hüzün both as a mystical state (engendered by the frustration of our common aim to be at one with Allah) and as an illness, the central preoccupation, as with all classical Islamic thinkers, was the cemaat, or the community of believers. He judged hüzün by the values of the cemaat and suggested remedies that return us to it: essentially he saw hüzün as an experience at odds with the communal purpose... Now we begin to understand hüzün as, not the melancholy of a solitary, but the black mood shared by millions of people together. What I am trying to explain is the hüzün of an entire city, of Istanbul. (Pamuk 83)

As suggested by the excerpts from Pamuk's memoirs, he makes an effort to put across to the reader what hüzün is and explains that, in order for a writer to put 
the topography of Istanbul into words, he cannot do so without tinting it with shades of hüzün. Although, by definition hüzün is a state of solitude, he sees a collective hüzün pervading the city, and, if we are to understand the symptoms of this illness, we have to consider that the collective population of the city has been estranged from something essential whose loss has left a deep spiritual void in the city. What Pamuk seems to be pointing to is that, if the remedy of hüzün is a return to the community, a retreat from solitude, how does one confront hüzün in the community itself? In this scenario hüzün precedes the individual; it is what causes a feeling of loss instead of vice versa, and it is an inherent human condition prevalent across Istanbullus. Hüzün has been traditionally understood as being a very private matter and to collectivise it means the blurring of yet another line by Pamuk, which is the line between the public and the private. It is at this juncture that The Museum of Innocence and Pamuk's memoirs of the city can be juxtaposed and compared as representative of these two spheres of human society. Pamuk's own role as the self-reflexive expository agent is crucial in the meaning he imbues in the representation of the city he lays out before the reader.

As stated previously, Pamuk's agency in the exposition of his small museum serves the purpose of producing a counter-narrative to the statesponsored narrative that endorses a linear historiography. This counter-narrative is not unitary but fragmented and collaged, offering one of many other potential narratives. Pamuk produces such a fragmented visual narrative in his museum by deploying hüzün, which is a private human condition, setting and socialising it via the public space of the museum. The collective hüzün described in Istanbul: Memories and the City is reflected in the public spaces of the city, and in the novel, it translates into the private realm of one man, Kemal. The relocation or 'socialisation' of hüzün, an emotional space which is at once private and made public owing to its collective nature as perceived by Pamuk, works by way of fractal distinctions. In order to elucidate this point, I will refer to the semiotics of public and private categories of space and discuss how that influences objects in a given space.

In her article "A Semiotics of the Public/Private Distinction", Susan Gal has put forward a semiotic understanding of the public/private distinction, which is a more nuanced approach than the conventional social analysis which developed in the nineteenth century and organises the social sphere into polarised halves, the public and the private, the community and the individual, rationality and sentiment (77). A semiotic approach recognises the distinction between public and private as a cartographic metaphor (a metaphor that helps to represent the 
mental organisation of space through cartographic visualisation) and, according to Gal, the two cultural categories of public and private are "indexical signs that are always relative: dependent for part of their referential meaning on the interactional context in which they are used" (80). Gal, while theorising about this distinction, has called the public/private dichotomy a 'fractal' distinction. A fractal, in the science of geometry, is a single pattern recurring inside itself, it is self-similar, and it has multiple nestings. The public/private dichotomy is a fractal distinction because it can be repeatedly reproduced within its contextual referents which are further categorised as being either public or private. For instance, a living room in the 'private' space of a house can be referred to as a public space where social gatherings take place; within the public space of a living room two persons can have an intimate conversation which creates the niche of a private space within the living room. According to Gal, a fractal distinction:

[C]an be projected onto different social "objects"

-activities, identities, institutions, spaces and interactions - that can be further categorised into private and public parts. Then, through recursivity (and recalibration), each of these parts can be recategorised again, by the same public/private distinction. It is crucial that such calibrations are always relative positions and not properties laminated onto the persons, objects, or spaces concerned. They are like Bakhtinian voicings or perspectives rather than fixed categories. (81)

The recalibration and recursivity that take place during the formation of fractal distinctions, which are fleeting and ephemeral categories, is a useful approach to understand the connection between Kemal's desire to musealise Füsun's memories in Pamuk's novel (along with other paraphernalia in the museum) and the hüzün from his memoirs on the city. As far as the novel is concerned, the space of the house in Çukurcuma, which was the (fictitious) Keskin family home, has been recalibrated into a public space as a museum. What was once a private domestic space has been re-categorised into the public sphere by virtue of advertisement and the rearrangement of certain objects of personal and domestic use in a manner similar to ethnographic exhibits preserved in glass cases. In order to retain the private and personal ambience of the Keskin home, as well as the fetishist nature of the collection of objects, however, Pamuk evokes a private frame of mind which is hüzün and uses it to make the transition from private to public. In his memoirs, Pamuk describes how the hüzün of the inhabitants of Istanbul has seeped into the very materiality of the city so that it appears foggy and grey in its streets and old buildings. For his project he collected all the objects that he deemed most saturated in hüzün, and he has showcased them in the Museum of Innocence which is reminiscent of his own old apartment. 
Accustomed as I was in the semi-darkness of our bleak museum-house, I preferred being indoors. The street below, the avenues beyond the city's poor neighbourhoods seemed as dangerous as those in a black-and-white gangster film [...] I love the overwhelming melancholy when I look at the walls of old apartment buildings and the dark surfaces of neglected, unpainted, fallen down wooden mansions: only in Istanbul have I seen this texture, this shading. (Pamuk 31)

Pamuk saw his own old family house as a museum of memories and untold stories of inhabitants whose images were captured in framed monochrome photographs. That same melancholy that he felt in the private space of his house seemed to have seeped out into the city, which is also a veritable palimpsest of generations and histories gone by. Although the rapid expansion and urbanisation around Istanbul have resulted in a number of new construction enterprises and the demolition of the old buildings in the city, altering the cityscape to a considerable extent, there remains remnants of the old city in the Çukurcuma district where the Museum of Innocence is situated (Fig. 1). This district is an assortment of old fallen-down houses, dilapidated apartments and new buildings under construction, and it gives an idea of what the Istanbul of the 1960s and 70s would have been like. It also adds to the ambience of hüzün and temporal stasis that the museum attempts to create. With the merging of the museum with its surroundings, the hüzün that Pamuk speaks of no longer remains private and becomes a collective sense of melancholy and angst.

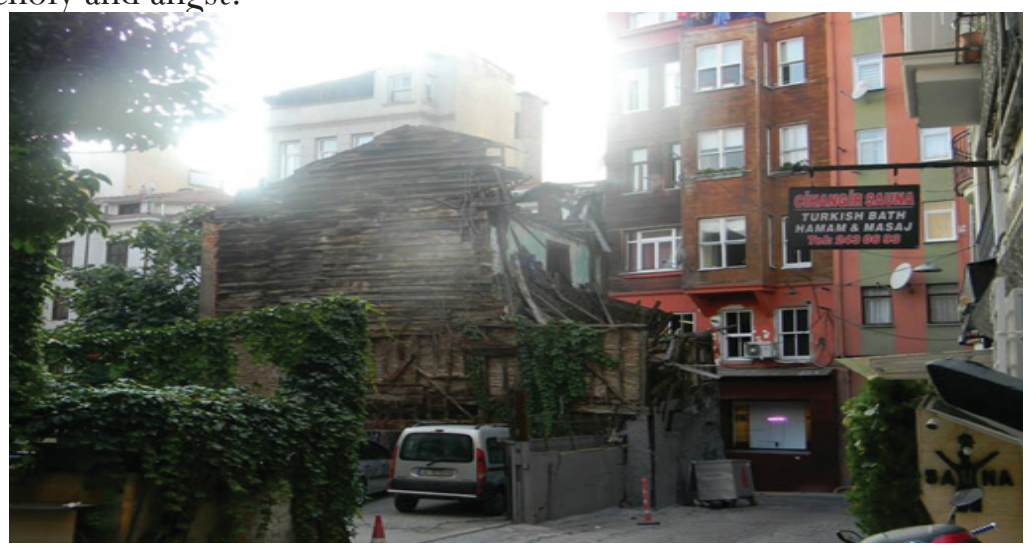

Fig. 1

When angst experienced at the individual level becomes a collective mood, it carries with it all the micro details of private life into the public domain where they take on socio-historical proportions. These micro details are preserved in the enshrined objects associated with Füsun's memory, the source of Kemal's sense of loss. In this way hüzün becomes a means of recalibrating the individual into 
the collective; it is a fractal distinction that also fragments the first personhood of the subject of the narrative of the museum (and the novel) because Kemal's biography, a private category, and Pamuk's agency as author, a public category, are interchangeable and even nested into one another, rendering the Museum of Innocence a fractal structure.

This interchangeability between the expository agent of the Museum of Innocence and Pamuk's authorial voice is also visible in his memoirs, Istanbul: Memories and the City, which shows that the museum, in actuality, captures Pamuk's own involvement in the city. At one place in his memoirs, Pamuk gives the example of one of four melancholic writers, Reat Ekrem Koçu, who had lived in Istanbul and was fascinated by curious stories about the city which he found in old, pre-Republican newspapers, as representing this hüzün:

We might see our encyclopaedist as a typical collector who, after a personal trauma, withdrew from the world to live amongst objects. Koçu, however, lacked the materialism of a classic collector - his interest was not in objects but in strange facts. But just as so many Western collectors have no idea whether their collection will end up in a museum or dispersed, he had no grand plan when the compulsion first overtook him: he began collecting out of attraction to any fact that told him something new about the city.

It was only after he realised that his collection would have no bounds that he hit on the idea of an encyclopaedia, and from then he remained aware of the 'thingness' of his collection. When Professor Semavi Eyice, the historian of Byzantine and Ottoman art, who'd known Koçu since 1944, and who'd written entries for the Encyclopaedia since its inception, wrote about Koçu after his death, he described his large library piled high with 'material' he kept in envelopes-newspaper cuttings, collections of pictures and photographs, dossiers and notes (now lost) compiled from his long years of reading the nineteenth-century newspapers.

[...] Unable to synthesise the sad story of the past into a text or enshrine it in a museum, Koçu spent his last years in an apartment piled high with mountains of paper. (147-48)

The parallels between Kemal's fetishist collection of objects belonging to Füsun, or in any way related to her memory, and Koçu's collection are too glaring to ignore, the only difference being that Kemal was able to create a museum out of his collection with Pamuk's help 'posthumously', while Koçu died before ever having completed his encyclopaedia on the city of Istanbul.

Koçu's real-life story finds a parallel in The Museum of Innocence when Kemal, while ruminating over various collectors who had lived in the city, ashamed of their collections but with whom he could relate, mentions one collector who appears surrealistically close to Koçu but is parodied with black humour:

In December 1996 a lone hoarder ("collector" would be the wrong word) 
named Necdet Adsiz, who lived in Tophane, a mere seven minute walk from the Keskins' house, was crushed to death beneath the accumulated piles of paper and old objects in his little house, not to be discovered, let alone mourned, until four months later, when in summer the stench coming from the house grew unbearable. (Pamuk 506)

Similar to Koçu, an academic, Pamuk himself writes the collector Kemal's story after his death, and he does it expressly by way of 'cataloguing' the objects on display in a museum:

In other words, a writer might undertake to write the catalogue in the same form as he might write a novel. But having no desire to attempt such a book myself, I asked: Who would do this for me?

This is how I came to seek out the esteemed Orhan Pamuk, who has narrated the story in my name, and with my approval. (512)

It is possible to draw the conclusion from this new modality of musealisation as being a private enterprise, or even from the manifesto proposed by Pamuk about a shift from 'monuments' to 'homes', that a museum, such as the Museum of Innocence, could be a step backwards in the larger socio-historical context of the museum as an institution, meaning that it could be a step backwards to the old cabinets of curiosities showcased in private exhibitions. But Pamuk's unique role as a self-reflexive expository agent and the fractal structure of his museum evade the drawing of such a conclusion. For one thing, although the purpose of this museum is not a didactic one and it does not instruct the visitor in any sort of progressivist teleology through an array of 'ethnic' artefacts, there is a chronotope, characteristic of a novel, that demands that the visitor follows a sequence of 'chapters' represented in glass cases numerically ordered from the first floor to the attic of the Keskin house. "I realised then that just as the line joining together Aristotle's moments was Time, so, too, the line joining together these objects would be a story" (512). Secondly, the narrative produced by the expository agent deploys a synecdochical rhetorical device in the 'discourse' of the actual Museum of Innocence which is similar to an ethnographic museum in calibration, but which is framed by a metafiction which determinedly challenges the metanarrative of any national museum with its self-referential narrative and it effectively supplants any grand narrative. Both these characteristics of a museum were absent in the cabinet of curiosities. Pamuk's 'small' museum is, therefore, an innovation in what has been an established state institution, and, instead of being didactic and choreographing a performative conformity, it compels its visitors to participate actively in the discourse of the museum which is imbedded in the material context of the novel's narrative.

The counter-narrative of the Museum of Innocence involves fictitious 
characters from a novel that goes by the same name, but the girl Füsun, in whose memory the museum poses as mausoleum, evades physical descriptions, and all that the visitor has to help in imaginary reconstructions of her are the material remnants of times spent with her by Kemal, the protagonist. Füsun is, in fact, a synecdoche of the whole of Kemal's life spent in search of something lost, a deep loss. Just as the objects in the museum are synecdochical representatives of her whole existence, she herself is the indexical synecdoche of Kemal's hüzün. In addition, as discussed earlier, Pamuk views hüzün as a collective condition of the citizens of Istanbul; Füsun can be said to stand for the hüzün pervading the city. What Turks should be viewing in their own museums are not bad imitations of Western art but their own lives. Instead of displaying the Occidentalist fantasies of our rich, our museums should show us our own lives. My museum comprises the life I shared with Füsun, the totality of our experience, and everything I've told you is true Orhan Bey [...] As visitors admire the objects and honour the memory of Füsun and Kemal, with due reverence, they will understand that, like the tales of Leyla and Mecnun or Hüsn and Ask, this is not simply a story of lovers, but of the entire realm, that is, of Istanbul. (521)

As evidenced in the novel, the residents of the city are coming to terms with social changes where westernisation has become a marker for class stratifications creating rifts between them and between residents and their city's past, and this explains their inexplicable sense of loss. This collective hüzün stems from mourning the void left by the replacement of a pluralistic culture with a homogenising, yet weak, imitation of western culture in the wake of obligatory modernisation that came with the package of the inevitable nationalised statehood. In such a state of affairs, the fractal structure of the Museum of Innocence provides a heterotopia of sorts, a buffer zone where the intersections of public and private help to erase, first of all, the demarcated public space of an important state institution, the museum, and, secondly, as a consequence of which visitors as participants of inter-subjectivity are given space and freedom to unravel their own first personhood, because they are in a dialogue with the narrative of the novel throughout their visit. Since the expository agent exposes himself as well, exhibiting the process of writing and planning the Museum of Innocence, his agenda is not invisibly inscribed onto the layout of the museum guiding and instructing the visitor, but, instead, it is a public space nested as a fractal distinction in the private collection of the protagonist Kemal, visible but not hegemonic. This is what we could call a 'homeopathic' cure for the scientific organisation of state institutions, the messy human condition embodied by hüzün, which leaves this small museum bereft of meaning-making strategies suggested by an otherwise deceptively objective expository agent. This 
fractal structure of the museum, thus, overthrows the state-sponsored narrative propagated in national museums, disturbing the ideological mapping of centre and periphery, putting on exhibition and, thus, focalising the marginalised private lives of individuals in the public space of a state institution.

In conclusion, I would like to draw attention to the space occupied by the objects put on display in the Museum of Innocence because this space houses a concentration or convergence of the city's hüzün as represented by Füsun. Her character is completely submerged in the material culture of the lower middle-class Istanbul of the 1970s, and there is anything but the transcendental about her; in fact, her appearance is so commonplace that Pamuk leaves out any identifying description of her physical appearance in the novel, and her character is easily confused with weak imitations or lookalikes. Yet she is the reason that Kemal has the fog of hüzün covering his eyes; that is her 'sorcery' over him. Füsun ultimately comes to stand for the naive or 'innocent' belief that to be civilised one needs to appear westernised and 'modern' and that one needs to shed off the cultural baggage of one's own origins and imitate and adopt a lifestyle advocated by the state. Füsun is the embodiment of Pamuk's hüzün as well as that of the city, and this imbeds the hüzün of the subject with the hüzün that engulfs the city of Istanbul, so that, in the space of the small Museum of Innocence, it is not Füsun's memory which is musealised but, by careful cataloguing of the peripheral existence of an individual in the face of considerable social changes, a crucial period of naive and innocent longing in the history of the entire city is musealised. This museum is 'innocent' because it has captured the naive longing of a society that was trying to fill a cultural void after the westernisation reforms and also because it contests discursive state-sponsored museums that propagated the nationalist progressivism of the nation state.

\section{Works Cited}

Bal, Mieke. Double Exposures: The Subject of Cultural Analysis. London: Routledge, 1996. Print.

Bennett, Tony. The Birth of the Museum: History, Theory, Politics. Oxon: Routledge, 1995. Print.

Brown, Chris. "State and Nation in Nineteenth Century International Political Theory." International Relations in Political Thought : Texts From the Ancient Greeks to the First World War. Ed. Brown, Chris and Nardin, Terry and Rengger, Nicholas. London: Cambridge UP, 2002. 457-469. Web. 30 Nov. 2016. 
Gal, Susan. "A Semiotics of the Private/Public Distinction.” Differences: A Journal of Feminist Cultural Studies 13.1 (2002): 77-95. Print.

Gardels, Nathan and Katherine Keating. "A Museum for the Person, not for Power." Huffpost, 28 Jan. 2014. Web. 14 Jan. 2016.

Goknar, Erdag. Orhan Pamuk, Secularism and Blasphemy:The Politics of the Turkish Novel. Oxon: Routeledge, 2013.

Huyssen, Andreas. Twilight Memories: Marking Time in a Culture of Amnesia. New York: Routledge, 1995. Print.

Kerpat, Kemal. The Politicisation of Islam. New York: Oxford UP, 2001. Print. Khaldun, Ibn. The Muqaddimah: An Introduction to History. Ed. N. J. Dawood. Trans. F. Rosenthal. Princeton: Princeton UP, 1969.

Pamuk, Orhan. Istanbul: Memories and the City. London: Faber and Faber, 2005. Print.

--- "Small Museums." The New York Times Style Magzine. 20 Mar. 2014: Nytimes. Web. 26 Aug. 2016.

---. The Museum of Innocence. New York: Random House, 2009. Print.

---. Interview by Nathan Gardels. “To Solve Turkey's Culture Clash, Old Elite Must Yield to Free Speech.” Csmonitor. Csmonitor, 11 Nov. 2009. Web. 29 Dec. 2016.

Samir, Amin. Eurocentricism. Trans. Russell Moore and James Membrez. New York: Monthly Review Press, 1989.

Shaw, Wendy. Possessors and Possessed: Museums, Archaeology, and the Visualisation of History in the Late Ottoman Empire. U of California Press, 2003. Print.

---. "National Museums in the Republic of Turkey: Palimpsests within a Centralised State.” Building National Museums in Europe 1750-2010, EuNaMus, European National Museums: Identity Politics, the Uses of the Past and the European Citizen, April 28-30, 2011. Ed. Gabriella Elgenius and Peter Aronsson. Bologna: 2011. 925-951. Print. 